University of Nebraska - Lincoln

DigitalCommons@University of Nebraska - Lincoln

Journal for the Advancement of Developing Institute for the Advancement of Developing Economies

Economies

2019

\title{
All For One Or Each For Her Own: Do Polygamous Families Share and Share Alike?
}

Kristin Mammen

CUNY College of Staten Island, kristin.mammen@csi.cuny.edu

Follow this and additional works at: https://digitalcommons.unl.edu/jade

Part of the Econometrics Commons, Growth and Development Commons, International Economics Commons, Political Economy Commons, Public Economics Commons, and the Regional Economics Commons

Mammen, Kristin, "All For One Or Each For Her Own: Do Polygamous Families Share and Share Alike?" (2019). Journal for the Advancement of Developing Economies. 39.

https://digitalcommons.unl.edu/jade/39

This Article is brought to you for free and open access by the Institute for the Advancement of Developing Economies at DigitalCommons@University of Nebraska - Lincoln. It has been accepted for inclusion in Journal for the Advancement of Developing Economies by an authorized administrator of DigitalCommons@University of Nebraska - Lincoln. 


\title{
All For One Or Each For Her Own: Do Polygamous Families Share and Share Alike?
}

\author{
Kristin Mammen* \\ Department of Economics, College of Staten Island, City University of New York, New York, \\ USA
}

\begin{abstract}
This paper examines whether the mother's rank (whether she is a senior or junior wife) in polygamous households in Côte d'Ivoire injects favoritism that could lead to differential investment in children (based on mother's rank), a concern that could cause an inefficient allocation of household resources. The hypothesis is that the younger is a junior wife relative to the senior wife, the greater favoritism she will receive from the husband, and the better her children will fare. This question is analyzed employing Ordinary Least Squares on a Living Standards Measurement Survey microdataset collected by the World Bank. An interesting pattern is found: whether the senior or junior children are advantaged depends on the age difference between the senior and junior wife. Senior children are at an advantage when the age gap is small; however, investments in senior children decline as this age gap increases. For example, the child of a senior wife is nearly 4 percentage points more likely to be enrolled in school as the child of a junior wife who is 5 years younger. With an age difference of 15 years, the child of a senior wife is 9 percentage points less likely to be enrolled. Inefficient disparities in investments of polygynous children potentially affect not only the well-being of those children but also Côte d'Ivoire as a society. The finding of disparity in schooling investments speaks to a role for policies that will incentivize more rational allocations to children such as increasing women's access to credit markets or paying mothers to keep children in school.
\end{abstract}

Keywords: Polygamy, intrahousehold allocation, children, school enrollment.

*Corresponding author: kristin.mammen@csi.cuny.edu

JEL Classification: D13, J12, J13, J22, J24

\section{INTRODUCTION}

Polygyny, the practice of a man marrying multiple wives, remains widespread in sub-Saharan Africa (Meekers, 1992; Munro, Kebede, Tarazona-Gomez, \& Verschoor, 2010; Timaeus \& Reynar, 1998), with important economic implications for the societies which house it. ${ }^{1}$ Theoretical and empirical research shows polygynous African families typically have lower socioeconomic status than one-wife families. Child health is poorer (Amankwaa, 1996; Amey, 2002; Arthi \& Fenske, 2018; Wagner \& Rieger, 2015) and child educational attainment is lower (e.g., Behaghel \& Lambert, 2017). Evidence also suggests women's status is lower in polygynous families than in one-wife families (Solanke, Kupoluyi, Abe, \& Bankole, 2018); polygynous wives report lower

\footnotetext{
${ }^{1}$ Polygyny denotes a man with multiple wives, polyandry a wife with multiple husbands. Polygamy refers to both these cases.
} 
life satisfaction (Hinks \& Davies, 2008) and suffer from poorer mental health; they experience more domestic violence (Ickowitz \& Mohanty, 2015) and are more resigned to it (Amo-Adjei \& Tuoyire, 2016; Uthman, Lawoko, \& Moradi, 2009).

Polygynous households save less which may impede economic growth at the national level (de Laiglesia \& Morrisson, 2008; Gould, Moav, \& Simhon, 2012; Tertilt, 2006). ${ }^{2}$ Addressing wellbeing within these families prompts questions about the intrahousehold allocation of resources among co-wives and their children. Although Becker's traditional microeconomic model of the household posits that households allocate investments efficiently over members (Becker, 1993), more recent evidence that children's well-being is correlated with how closely related they are to the decision-maker in the household has put the assumption of rational household decision-making into question (e.g., Case \& Paxson, 2001; Leroy, Razak, \& Habicht, 2008). If the one-wife family is inefficient, it is likely that the polygynous family is even more so. Co-wives compete vigorously for the husband's resources and attention for themselves and their children (Jankowiak, Sudakov, $\&$ Wilreker, 2005) and it seems unlikely that mothers are concerned with the marginal product of investments in their children relative to another wife's children. Only a few studies have investigated child outcomes within polygynous families; ${ }^{3}$ much of the existing evidence is from small samples (e.g., Strassman, 1997). In this paper, a large microdataset from Côte d'Ivoire was used to investigate empirically if the investments a child receives depend on the rank of his mother - whether she is a senior (first) wife or a junior (second and higher order) wife.

In Côte d'Ivoire, as in many polygynous societies, senior wives are typically close in age to their husbands (Clignet \& Sween, 1969, Sween \& Clignet, 1978) and accorded traditional privileges which they may use to advantage their children (e.g., Clignet, 1970, p. 35). However, as a husband ages and becomes more financially established, he can afford to marry more "socially valuable" women as junior wives - younger, from a higher status family, or more educated than the first wife (Clignet, 1970, p. 91, p. 242). ${ }^{4}$ A husband's favoritism for such a junior wife may result in more resources being allocated to her children. This cultural context makes it difficult to predict whether senior or junior wives will have more 'clout'; thus, it is an empirical question whether the gain, if any, will accrue to the children of senior or junior wives. The objective of this paper is to examine the effect of a wife's rank on her child's school enrollment, productive activities, and educational attainment. The hypothesis is that the younger is a junior wife relative to the senior wife, the greater favoritism she will receive from the husband, and the better her children will fare. The identification assumption is that on average the children of senior and junior wives (who will be

\footnotetext{
${ }^{2}$ A possible exception is in Senegal where Boltz and Chort (2016) find a positive effect of the risk of polygyny - the husband marrying an additional wife - on wives' savings.

${ }^{3}$ Matz (2016) investigates polygynous household in rural Ethiopia and finds senior children have higher school attendance relative to junior children. With data on wives' characteristics at the time of marriage, she demonstrates that wife rank correlates with 'high productivity' characteristics such as early marriage and higher wealth of the wives' origin family. Gibson and Mace (2007) find similar results for child nutrition in Ethiopia. Kazianga and Klonner (2009) show that while senior wives in rural Mali achieve efficient investments in their offspring, junior wives do not, due to their weak bargaining position in the household, leading to higher mortality for junior girls relative to boys. These papers do not specifically address how senior and junior wives' bargaining power may change over time.

${ }^{4}$ In 1975 the singulate mean age at marriage for women (men) was 18.4 (27.9) in Côte d'Ivoire (Pebley \& Mbugua, 1989).
} 
referred to as senior children and junior children) are equally productive so that if the household is making rational allocations, the children should receive the same levels of investments, ceteris paribus. That is, that the rank of the wife is not correlated with the productivity of her children. The plausibility of this assumption will be discussed later in the paper.

\section{DATA}

\subsection{Summary Statistics: Polygyny and Polygynous Households in Côte d'Ivoire}

The rich data analysed here come from the Côte d'Ivoire Living Standards Survey (CILSS) conducted from 1985 to 1988 by the Department of Statistics of Côte d'Ivoire with support from the World Bank. ${ }^{5}$ The CILSS records relationship to the household head for all household members. Each individual can also be linked to his or her father, mother, and spouse if they reside in the household. Therefore, all men, women, and children in polygynous families (marriages with multiple wives) can be identified. The data show that polygyny is common in Côte d'Ivoire. Table 1 presents estimates of standard demographic measures of polygyny: $p$ is the proportion of husbands who have more than one wife; $f$ is the proportion of all married women who are in polygynous marriages; $m$ is the ratio of currently married women to currently married men; and $w$ is the number of wives per polygynist (Goldman \& Pebley, 1989; van de Walle, 1968). About $25 \%$ of married men in the sample are polygynists, with an average of about two and a half wives per polygynous husband. If mother's rank is found to effect investments in children, the number of women and children affected is substantial, because over $40 \%$ of married women are married to polygynists, and $24 \%$ of children in the sample are children of polygynous marriages. ${ }^{6}$

\section{Table 1: Measures of Polygyny}

$p$ proportion of husbands who have more than one wife

$f$ proportion of all married women who are in polygynous marriages

$m$ ratio of currently married women to currently married men

$w$ number of wives per polygynist

proportion children ages 19 and under who are children of polygynous marriages

Data: Côte d'Ivoire Living Standards Survey, 1985-1988 (pooled sample).

Table 2 presents summary statistics for polygynous households, where a polygynous household is defined as one comprising at least one polygynous marriage. Statistics for one-wife

\footnotetext{
${ }^{5}$ A random sample of approximately 1,600 households was interviewed each year. There was a rolling panel element in the data; in the second, third and fourth years, 800 households from the previous year were to be reinterviewed and 800 new households chosen (Venkatamaran, 1996, p. 1). The data are pooled and the estimations control for year effects.

${ }^{6}$ These figures are similar to those in multiple other sources and have not declined much over time ( $c f$., Munro, et al., 2010), despite the fact that polygyny has been banned in Côte d'Ivoire since 1964 (Toungara, 1994).
} 
Table 2: Household Characteristics

\begin{tabular}{|c|c|c|c|c|c|}
\hline & 1 & 2 & 3 & $\overline{44}$ & \multirow{3}{*}{$\begin{array}{c}5 \\
\text { Difference } \\
\text { (polyg. - } \\
\text { monog.) } \\
\text { point est. } \\
\text { (s.e.) }\end{array}$} \\
\hline & \multicolumn{2}{|c|}{$\begin{array}{l}\text { Polygynous households } \\
1,539 \text { obs }\end{array}$} & \multicolumn{2}{|c|}{$\begin{array}{c}\text { Monogamous households } \\
4,849 \text { obs }\end{array}$} & \\
\hline & $\begin{array}{l}\text { mean } \\
\text { [s.d.] }\end{array}$ & obs & $\begin{array}{l}\text { mean } \\
{[\text { s.d.] }}\end{array}$ & obs & \\
\hline household size & $\begin{array}{l}11.58 \\
{[5.91]}\end{array}$ & 1,539 & $\begin{array}{c}6.12 \\
{[3.79]}\end{array}$ & 4,849 & $\begin{array}{c}5.46 \\
(0.26)\end{array}$ \\
\hline \multirow[t]{2}{*}{$\begin{array}{l}\text { \# children in household } \\
\text { under } 19\end{array}$} & 7.31 & 1,504 & 4.32 & 4,087 & 2.98 \\
\hline & {$[4.35]$} & & {$[2.78]$} & & $(0.19)$ \\
\hline proportion rural & $\begin{array}{c}0.70 \\
{[0.46]}\end{array}$ & 1,539 & $\begin{array}{c}0.50 \\
{[0.50]}\end{array}$ & 4,849 & $\begin{array}{c}0.20 \\
(0.03)\end{array}$ \\
\hline per capita expenditure & $\begin{array}{c}166.62 \\
{[102.42]}\end{array}$ & 1,539 & $\begin{array}{c}267.67 \\
{[233.93]}\end{array}$ & 4,849 & $\begin{array}{l}-101.08 \\
(13.56)\end{array}$ \\
\hline age of head & $\begin{array}{c}51.58 \\
{[12.69]}\end{array}$ & 1,539 & $\begin{array}{c}45.46 \\
{[14.21]}\end{array}$ & 4,848 & $\begin{array}{c}6.11 \\
(0.61)\end{array}$ \\
\hline \multirow[t]{2}{*}{$\begin{array}{l}\text { age of senior/sole wife of } \\
\text { head }\end{array}$} & 43.59 & 1,530 & 36.08 & 3,561 & 7.51 \\
\hline & [12.21] & & {$[12.50]$} & & $(0.55)$ \\
\hline $\begin{array}{l}\text { proportion heads with any } \\
\text { schooling }\end{array}$ & $\begin{array}{c}0.22 \\
{[0.42]}\end{array}$ & 1,539 & $\begin{array}{c}0.40 \\
{[0.49]}\end{array}$ & 4,843 & $\begin{array}{l}-0.18 \\
(0.02)\end{array}$ \\
\hline \multirow[t]{2}{*}{$\begin{array}{l}\text { proportion senior/sole } \\
\text { wives of heads with any } \\
\text { schooling }\end{array}$} & 0.07 & 1,514 & 0.25 & 3,513 & -0.18 \\
\hline & {$[0.26]$} & & {$[0.43]$} & & $(0.02)$ \\
\hline \multirow[t]{2}{*}{$\begin{array}{l}\text { proportion kids } 7-12 \\
\text { currently enrolled }\end{array}$} & 0.46 & 1,359 & 0.56 & 3,365 & -0.10 \\
\hline & {$[0.42]$} & & {$[0.44]$} & & $(0.02)$ \\
\hline \multirow{2}{*}{$\begin{array}{l}\text { school expenditure for } 7 \text { - } \\
12 \mathrm{~s}\end{array}$} & 13.28 & 1,242 & 20.30 & 2,707 & -7.02 \\
\hline & [19.41] & & [33.86] & & $(1.65)$ \\
\hline \multirow[t]{2}{*}{$\begin{array}{l}\text { proportion kids } 13-16 \\
\text { currently enrolled }\end{array}$} & 0.35 & 973 & 0.39 & 2,046 & -0.04 \\
\hline & {$[0.42]$} & & {$[0.45]$} & & $(0.02)$ \\
\hline \multirow{2}{*}{$\begin{array}{l}\text { school expenditure for } 13- \\
16 \mathrm{~s}\end{array}$} & 22.48 & 973 & 27.13 & 2,046 & -4.65 \\
\hline & [35.94] & & [46.22] & & $(2.48)$ \\
\hline
\end{tabular}

Notes: Differences are significant at the 1\% level except school enrollment and expenditures for 13-16 year olds which are significant at $10 \%$.

$\mathrm{n}=6,388$ households (pooled sample): 1,588 households were interviewed in the first year, 1,600 in each of years 2-4. Panel households supply two observations, each from a different year. Polygynous 
households are households which contain at least one polygynous marriage; all other households are classified as monogamous.

Expenditures are in 1,000s of 1985 CFA francs and account for regional price differences using the Combined Price Index (Venkatamaran, 1996). Means for number of children, proportions of children, and school expenditures are conditional on children in the designated age group being present in the household. School expenditure means are for all children in the age group, unconditional on being enrolled in school. They include contributions to parent's associations, uniforms and sports clothes, books and school supplies, transportation to school, cafeteria, board and lodging, tuition and registration fees, and other.

("monogamous") households are provided for comparison. About $25 \%$ of households contain at least one polygynous marriage; the majority of polygynous husbands are heads of households, but there are some non-heads. Polygynous households are larger, more likely to be rural, and have lower per capita expenditure. The heads and wives of heads in polygynous households are less likely to have any education. Children in polygynous households are less likely to be enrolled in school from ages seven to sixteen, and expenditures on their schooling are lower on average. ${ }^{7}$

\subsection{Summary Statistics: Senior and Junior Wives}

Table 3 presents average characteristics of senior and junior wives in the sample. ${ }^{8}$ The number of senior wives is greater than the number of polygynous households in Table 2 because a household may contain more than one polygynous marriage. Column 5 shows the raw differences between senior and junior wives. Senior wives are older on average than junior wives and their husbands are about the same age. Senior wives are slightly less likely to have any schooling than junior wives. However, the differences in column 5 are affected by the fact that senior wives are older on average. To allow for age and cohort effects, the wife characteristic in each row is regressed on an indicator for being a senior wife and a full set of indicators for age. The coefficient on the indicator dummy and its standard error, presented in column 6, give the age-adjusted difference between senior and junior wives and its significance. When the effects of age are controlled for, we see that the junior wives' husbands are older on average than senior wives' husbands: if we consider a senior wife and a junior wife who are of the same age, the senior wife's husband will be about 8 years younger than the junior wife's husband. Junior wives are slightly more likely to have some education, significant at the $10 \%$ level.

\footnotetext{
${ }^{7}$ In Côte d'Ivoire, primary education lasts for 6 years, starting at age 6. At the end of primary school, students take a national exam to obtain a diploma (certificat d'étude primaires or CEPE) which is used for selection of students for secondary schools. Lower secondary school (which will be referred to as "middle school") has 4 grades, upper secondary 3 grades (Sylla, 1992). Repetition of grades is common (Den Tuinder, 1978, p. 280). School attendance was not compulsory during the time of the survey (Tansel, 1997, Appendix).

${ }^{8}$ The oldest wife was categorized as the senior wife and the younger wives as junior wives. The wives' ages are probably good proxies for the dates they married the husband, because men seek younger women to be later wives (Clignet \& Sween, 1969). Marriage histories are not collected in the CILSS, but even if marriage dates were available, they would not necessarily be more precise markers of wives' rank, because marriage was not a discrete event in Côte d'Ivoire during this period, but rather typically proceeded in stages (Meekers, 1992). The sequencing of union formation events such as onset of sexual activity, cohabitation, and marriage ceremony differed across women and there was no one event which universally divided single from married women.
} 
Table 3: Wife Characteristics

\begin{tabular}{|c|c|c|c|c|c|c|}
\hline & 1 & 2 & 3 & 4 & \multirow{3}{*}{$\begin{array}{c}5 \\
\text { Difference } \\
\text { (senior - } \\
\text { junior) } \\
\text { point est. } \\
\text { (s.e.) } \\
\end{array}$} & \multirow{3}{*}{$\begin{array}{c}6 \\
\text { Age- } \\
\text { adjusted } \\
\text { difference } \\
\text { point est. } \\
\text { (s.e.) } \\
\end{array}$} \\
\hline & \multicolumn{2}{|c|}{ Senior wives } & \multicolumn{2}{|c|}{ Junior wives } & & \\
\hline & $\begin{array}{l}\text { mean } \\
{[\text { s.d. }]}\end{array}$ & obs & $\begin{array}{l}\text { mean } \\
{[\text { s.d. }]}\end{array}$ & obs & & \\
\hline Age & $\begin{array}{c}43.17 \\
{[12.32]}\end{array}$ & 1571 & $\begin{array}{c}34.20 \\
{[11.55]}\end{array}$ & 2041 & $\begin{array}{c}8.97 * * * \\
(0.27)\end{array}$ & -- \\
\hline Age of husband & $\begin{array}{c}50.98 \\
{[12.80]}\end{array}$ & 1571 & $\begin{array}{c}51.97 \\
{[12.58]}\end{array}$ & 2041 & $\begin{array}{c}-0.99 * * * \\
(0.15)\end{array}$ & $\begin{array}{c}-7.89 * * * \\
(0.26)\end{array}$ \\
\hline $\begin{array}{l}\text { Proportion with any } \\
\text { schooling }\end{array}$ & $\begin{array}{c}0.07 \\
{[0.25]}\end{array}$ & 1554 & $\begin{array}{c}0.10 \\
{[0.30]}\end{array}$ & 1998 & $\begin{array}{c}-0.03 * * * \\
(0.01)\end{array}$ & $\begin{array}{l}0.02 * \\
(0.01)\end{array}$ \\
\hline
\end{tabular}

Notes: $*$ significant at $10 \% ; * *$ significant at $5 \% ; * * *$ significant at $1 \%$. Standard errors in parentheses robust to heteroskedasticity and correlation within clusters. In the pooled sample, ranked by age, of 2,041 junior wives, 1,571 are second wives, 383 third, 70 fourth, 14 fifth, and three are sixth wives. Ageadjusted differences are obtained by regressing the wife characteristic on an indicator for being a senior wife and a full set of age indicators.

\subsection{Summary Statistics: Senior and Junior Children}

Table 4 presents summary statistics for children of polygynous families in the CILSS data. The current investigation focuses on children 13 to 16 years old, of an age to be attending middle school. Both schooling expenditures (e.g., fees, books, and uniforms, as can be seen in Table 3) and the opportunity cost of children's time are higher at these ages than for primary-school-aged children, so resource constraints are more binding. ${ }^{9}$ Older children were not examined because during this time period very few students attended upper secondary school. The outcomes studied are whether the child is enrolled in school; whether the child performs any work (market work or home production); and the years of schooling attained by the child.

\section{METHODOLOGY}

The empirical specification is

$$
\begin{gathered}
E=\beta_{0}+\beta_{1} \cdot 1(\text { junior child })+\beta_{2} \cdot 1(\text { junior child }) \cdot \text { Age Diff }+ \\
\beta_{3} \cdot 1(\text { senior child }) \cdot \text { Age Diff }+X^{\prime} \cdot \beta_{4}+\varepsilon
\end{gathered}
$$

$E$ denotes the measure of investment in the child. The child's mother's rank is specified by an indicator function which takes on the value of ' 1 ' if the child's mother is a junior wife, and is otherwise ' 0 '. The variable AgeDiff denotes the age difference between the household's senior wife and the youngest wife (referred to here as mothers' age difference); it is interacted with both

\footnotetext{
${ }^{9}$ The increase in opportunity cost of children's time is predicted by economic theory, assuming that they are more productive than are younger children.
} 
the junior child indicator and a senior child indicator, because its effects prove to be quite different for junior and senior children. The omitted category relative to junior children is senior children, so $\beta_{0}$ represents the effect of being a senior child given the oldest and youngest wives in the household are the same age $($ AgeDiff $=0)$. The vector $X$ contains other characteristics of the child and her household; the unreported controls are listed in the notes of Table 5.

Table 4: Child Characteristics

\begin{tabular}{|c|c|c|c|c|c|}
\hline & 1 & 2 & 3 & 4 & \multirow{3}{*}{$\begin{array}{c}5 \\
\text { Differenc } \\
\text { (senior - } \\
\text { junior) } \\
\text { point est. } \\
\text { (s.e.) }\end{array}$} \\
\hline & \multicolumn{2}{|c|}{$\begin{array}{l}\text { Children of senior } \\
\text { wives }\end{array}$} & \multicolumn{2}{|c|}{$\begin{array}{l}\text { Children of junior } \\
\text { wives }\end{array}$} & \\
\hline & $\begin{array}{l}\text { mean } \\
\text { [s.d.] }\end{array}$ & obs & $\begin{array}{l}\text { mean } \\
\text { [s.d.] }\end{array}$ & obs & \\
\hline \multicolumn{6}{|l|}{ Ages 13 to 16: } \\
\hline proportion currently enrolled & $\begin{array}{c}0.42 \\
{[0.49]}\end{array}$ & 580 & $\begin{array}{c}0.43 \\
{[0.50]}\end{array}$ & 480 & $\begin{array}{l}-0.01 \\
(0.04)\end{array}$ \\
\hline $\begin{array}{l}\text { proportion who have obtained } \\
\text { CEPE, given they have } 6 \text { years of }\end{array}$ & 0.65 & 268 & 0.61 & 216 & 0.04 \\
\hline & 0.48 & & [0.49] & & $(0.05)$ \\
\hline any work (indicator) & $\begin{array}{c}0.37 \\
{[0.48]}\end{array}$ & 573 & $\begin{array}{c}0.40 \\
{[0.49]}\end{array}$ & 475 & $\begin{array}{l}-0.03 \\
(0.04)\end{array}$ \\
\hline schooling (years) & $\begin{array}{c}5.14 \\
{[3.52]}\end{array}$ & 580 & $\begin{array}{c}5.08 \\
{[3.71]}\end{array}$ & 480 & $\begin{array}{c}0.59 \\
(0.28)\end{array}$ \\
\hline Ages 7 to 12: & & & & & \\
\hline proportion currently enrolled & $\begin{array}{c}0.49 \\
{[0.50]}\end{array}$ & 837 & $\begin{array}{c}0.48 \\
{[0.50]}\end{array}$ & 911 & $\begin{array}{c}0.02 \\
(0.03)\end{array}$ \\
\hline any work (indicator) & $\begin{array}{c}0.21 \\
{[0.41]}\end{array}$ & 833 & $\begin{array}{c}0.20 \\
{[0.40]}\end{array}$ & 911 & $\begin{array}{c}0.01 \\
(0.02)\end{array}$ \\
\hline schooling (years) & $\begin{array}{c}2.66 \\
{[2.53]}\end{array}$ & 837 & $\begin{array}{c}2.55 \\
{[2.53]}\end{array}$ & 911 & $\begin{array}{c}0.10 \\
(0.13)\end{array}$ \\
\hline $\begin{array}{l}\text { Ages } 13 \text { to 19: } \\
\text { proportion children who have }\end{array}$ & 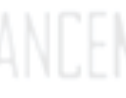 & & & & MEO \\
\hline $\begin{array}{l}\text { obtained CEPE, given they have } 6 \\
\text { years of education }\end{array}$ & $\begin{array}{r}0.71 \\
{[0.45]} \\
\end{array}$ & 620 & $\begin{array}{r}0.66 \\
{[0.47]} \\
\end{array}$ & 437 & $\begin{array}{r}0.05 \\
(0.35) \\
\end{array}$ \\
\hline
\end{tabular}

Notes: All differences are not statistically significant at the 10\% level. Expenditure in 1,000s of 1985 CFA francs. School expenditure means are unconditional on being enrolled. 
Table 5: Investments and Outcomes for Polygynous Children

\begin{tabular}{|c|c|c|c|c|}
\hline \multirow[b]{3}{*}{ Dependent Variables: } & \multicolumn{2}{|c|}{ Linear Probability Models } & \multicolumn{2}{|c|}{ OLS } \\
\hline & 1 & 2 & 3 & 4 \\
\hline & $\begin{array}{l}\text { Enrolled } \\
\text { (indicator) }\end{array}$ & $\begin{array}{l}\text { Any Work } \\
\text { (indicator) }\end{array}$ & $\begin{array}{l}\text { Schooling } \\
\text { attained } \\
\text { (years) }\end{array}$ & $\begin{array}{c}\text { Schooling } \\
\text { attained } \\
\text { (years) }\end{array}$ \\
\hline [mean] & {$[0.43]$} & {$[0.38]$} & [5.11] & {$[5.75]$} \\
\hline Sample Age Range & $13-16$ & $13-16$ & $13-16$ & $20-25$ \\
\hline \multirow[t]{2}{*}{ Junior child } & $-0.103^{* *}$ & 0.059 & -0.45 & $-1.70^{* *}$ \\
\hline & $(0.051)$ & $(0.052)$ & $(0.37)$ & $(0.85)$ \\
\hline \multirow{2}{*}{$\begin{array}{l}\text { Junior child*Mothers' age } \\
\text { difference }\end{array}$} & 0.001 & -0.002 & -0.04 & 0.02 \\
\hline & $(0.004)$ & $(0.003)$ & $(0.03)$ & $(0.05)$ \\
\hline \multirow{2}{*}{$\begin{array}{l}\text { Senior child*Mothers' age } \\
\text { difference }\end{array}$} & $-0.012 * * *$ & $0.006 * *$ & $-0.10 * * *$ & $-0.16 * * *$ \\
\hline & $(0.003)$ & $(0.003)$ & $(0.03)$ & $(0.05)$ \\
\hline \multirow[t]{2}{*}{ Female } & $-0.190 * * *$ & $0.102 * * *$ & $-1.37 * * *$ & $-1.75 * * *$ \\
\hline & $(0.035)$ & $(0.029)$ & $(0.25)$ & $(0.48)$ \\
\hline \multirow[t]{2}{*}{ Constant } & $0.387 * *$ & $0.28 * *$ & $2.82 * *$ & $6.98 * * *$ \\
\hline & $(0.164)$ & $(0.128)$ & $(1.23)$ & $(2.48)$ \\
\hline $\mathrm{R}^{2}$ & 0.15 & 0.24 & 0.22 & 0.31 \\
\hline$n$ & 1,060 & 1,048 & 1,060 & 462 \\
\hline \multicolumn{5}{|c|}{$\mathrm{H}_{0}:$ Junior child $*$ AgeDiff $=$ Senior child $*$ AgeDiff } \\
\hline \multirow{2}{*}{$\begin{array}{l}\text { F statistic } \\
\text { p-value }\end{array}$} & 9.47 & 4.55 & 4.34 & 7.31 \\
\hline & 0.002 & 0.034 & 0.039 & 0.008 \\
\hline \multicolumn{5}{|c|}{$\mathrm{H}_{0}:$ junior child $*$ AgeDiff $=$ senior child $*$ AgeDiff $=0$} \\
\hline F statistic & 7.83 & 2.96 & 7.60 & 6.26 \\
\hline p-value & 0.001 & 0.054 & 0.001 & 0.003 \\
\hline
\end{tabular}

Notes: * statistically significant at $10 \% ; * *$ at $5 \% ; * * *$ at $1 \%$.

Standard errors in parentheses robust to heteroskedasticity and correlation within clusters.

Other regressors not reported include indicators for child age; whether the child's mother has any education, the child's "other mother(s)" has any education, and the child's father has any education; father's age; mother's age; the number of co-wives in the family; the child's birth order among her father's children and the child's birth order among her mother's children; the number of children of the child's own mother; the number of children of the other wife who has the most children; household size; total household expenditure and its square* $10^{-6}$ in 1,000s of 1985 CFA francs. Regressions also include indicators for year and region (rural regions East Forest, West Forest, and Savannah and urban regions Abidjan (the largest city and the omitted category) and Other Cities, not Abidjan).

Column 2 has fewer observations than 1 or 3 because of missing values for the work questions. The results in columns 1 and 3 are robust to using the slightly smaller sample of column 2 .

\section{RESULTS AND DISCUSSION}

\subsection{Enrollment Results}


Table 5 presents the results of ordinary least squares regressions on outcomes, starting with an indicator for being enrolled in school as the dependent variable in column $1 .{ }^{10}$ The negative and significant coefficient on the junior child indicator indicates that junior children are 10 percentage points less likely to be enrolled relative to their senior counterparts; however the coefficients on the AgeDiff interactions show this effect is mediated by the mothers' age gap. The coefficient on Senior child*AgeDiff gives the effect on the probability of a senior child's enrollment of adding an additional year to the age difference between the household's senior wife and the youngest wife, while the coefficient on Junior child*AgeDiff gives this effect on the probability of a junior child's enrollment. There is a negative and significant coefficient on Senior child*AgeDiff (-0.012, pvalue $=0.00)$ and a positive (though small and insignificant) coefficient $(0.001, \mathrm{p}$-value $=0.78)$ on Junior child*AgeDiff. The end result is that senior children in a household with wives' ages tightly clustered indeed fare better than junior children; but the enrollment of senior children relative to junior children declines in families with larger age gaps, as depicted in Figure 1 panel A. The squares (circles) show the enrollment at each AgeDiff for senior (junior) children; the diamonds show the difference; and the symbols are filled in for statistically significant differences. The dashed-line figure (labelled "Fraction children with this value of mother's age difference") shows the distribution of children across values of AgeDiff, to illustrate the relevant proportion of the sample for each difference in enrollment. ${ }^{11}$ (Note the two different scales on the two y-axes: the left y-axis, "Predicted fraction children enrolled," is the scale for the results computed from the regression coefficients Senior child*AgeDiff and Junior child*AgeDiff; the right y-axis "Fraction children with this value of mothers' age difference" is the scale for the relative frequency of children for each age difference value.) As can be seen in the graph, the significant differences in enrollment are at mothers' age differences of 2 years or less, and 15 years or greater. The crossover where senior children's enrollment descends below juniors' occurs at an age difference of about 7.9 years; the average (median) age difference is $11.2(10)$ years (author's calculations from the data). So, the effects are significant for a substantial subset of the children.

Referring back to equation (1), in order to fix ideas, the outcome $\mathrm{E}$ is designated as enrollment. Now suppose there is an AgeDiff equal to 5 years. In this sample calculation it is assumed that the junior $(\mathrm{J})$ and senior $(\mathrm{S})$ child are otherwise identical, so the effects of the variables in $X$ will difference out. The difference in enrollment between the senior and junior child:

$$
\left.\left.\widehat{E_{S}}-\widehat{E_{J}}=\widehat{\left(\beta_{0}\right.}+\widehat{\beta_{3}} \cdot \text { Age Diff }+X^{\prime} \cdot \widehat{\beta_{4}}+\varepsilon\right)-\widehat{\left(\beta_{0}\right.}+\widehat{\beta_{1}}+\widehat{\beta_{2}} \cdot \operatorname{AgeDiff}+X^{\prime} \cdot \widehat{\beta_{4}}+\varepsilon\right)
$$

which, assuming that the characteristics $X$ are identical, simplifies to:

$$
\widehat{E_{S}}-\widehat{E_{J}}=-\widehat{\beta_{1}}+\left(\widehat{\beta_{3}}-\widehat{\beta_{2}}\right) \cdot \text { Age Diff }
$$

and with the enrollment coefficients inserted,

$$
\widehat{E_{S}}-\widehat{E_{J}}=0.103+(-0.012-0.001) \cdot \text { Age Diff }
$$

If AgeDiff $=5$,

$$
\widehat{E_{S}}-\widehat{E_{J}}=0.103-0.013 \cdot 5=0.103-0.065=0.038
$$

\footnotetext{
${ }^{10}$ For ease of interpretation, ordinary least squares is used for the analysis of the binary variables Enrolled (column 1) and Any Work (column 2); results are robust to using probit analysis.

${ }^{11}$ This is the distribution of senior and junior children pooled; separate histograms for both groups look extremely similar.
} 


\section{A. Fraction enrolled}

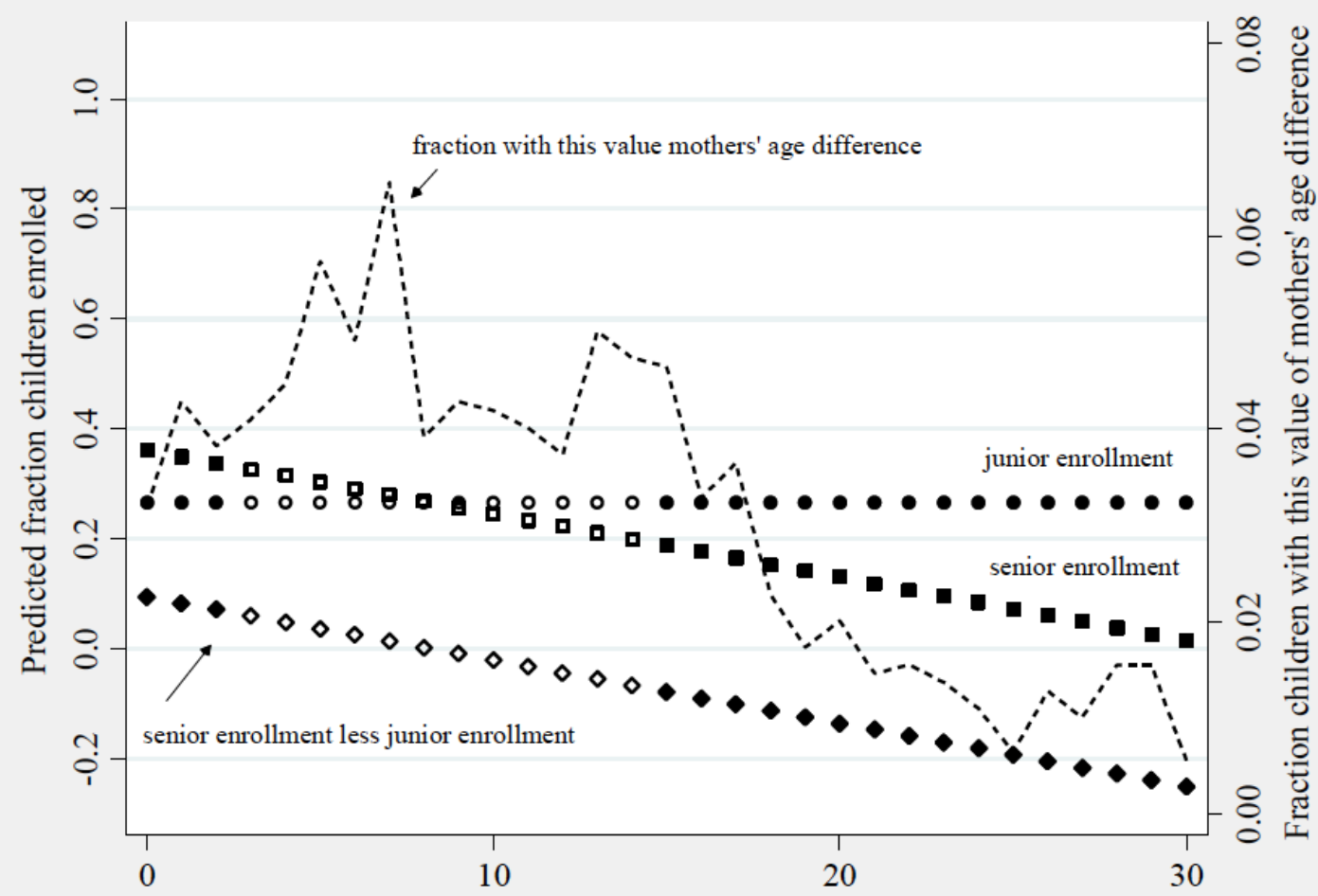

\section{B. Fraction working}

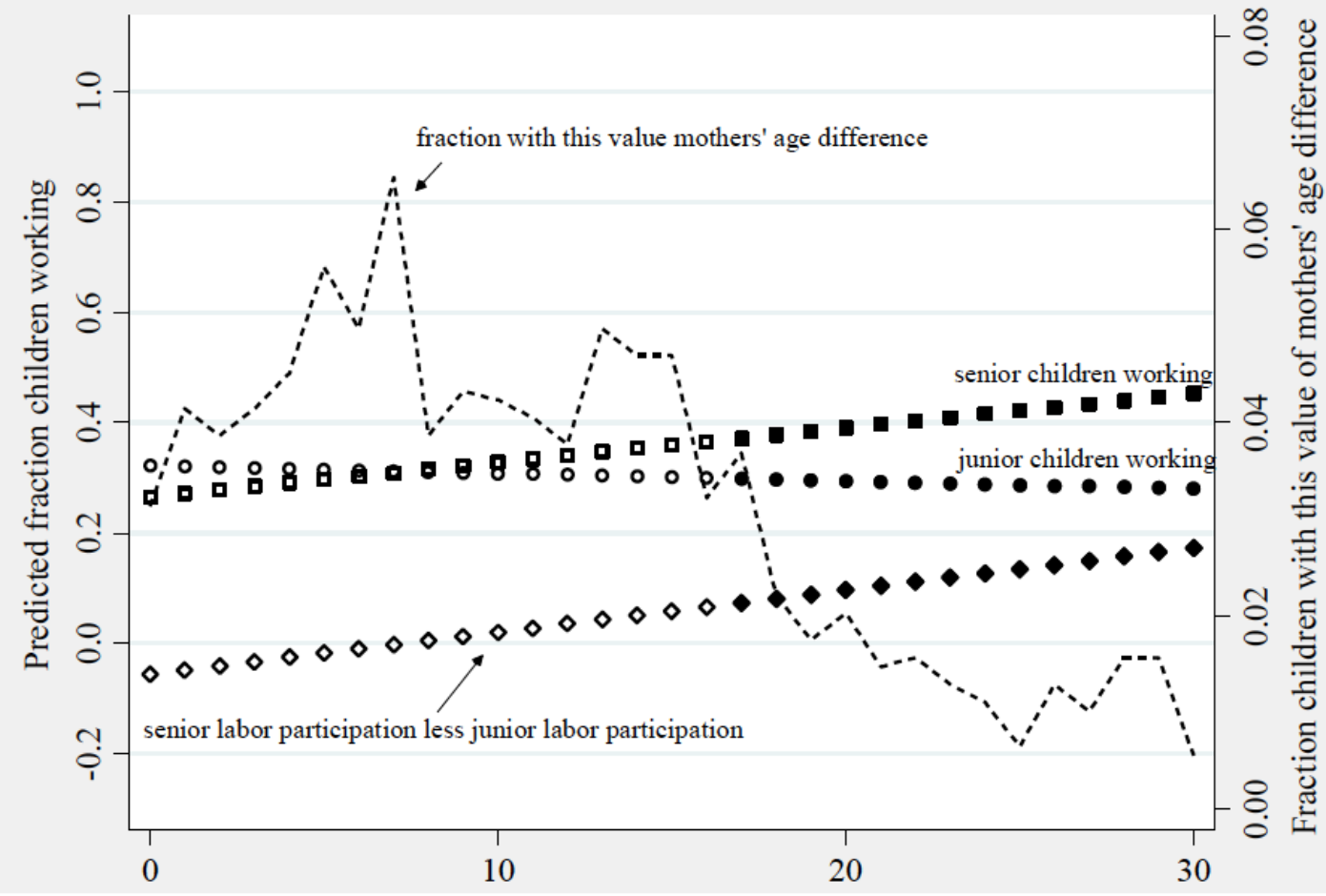

age difference: senior mother's less junior mother's

Figure 1: Polygynous Children's Time Use (Ages 13-16) 
Senior children are four percentage points more likely to be enrolled in school. However if AgeDiff $=15, \widehat{E_{S}}-\widehat{E_{J}}=0.103-0.195=-0.092$, so senior children with mothers' age difference of 15 years are 9 percentage points less likely to be enrolled in school relative to the junior counterparts. This is a substantial difference given that 43 percent of this sample is enrolled.

The coefficient for Junior child*AgeDiff is not statistically significantly different from zero in this or the following regressions, and in columns two and three neither is the junior child indicator. But in all specifications the Senior child*AgeDiff coefficient, the driver for the difference between senior and junior child outcomes, is significant (Table 5, Senior child * Mothers' age difference, all columns). Additionally, the two lowest rows in Table 5 show results of F-tests for the null hypotheses 1) that the coefficients on Junior child*AgeDiff and Senior child*AgeDiff are equal and 2) that these two coefficients are jointly insignificant. These hypotheses are rejected at the $5 \%$ level for all four specifications. ${ }^{12}$

Turning to the other covariates in the enrollment specification: the coefficient for gender is reported because it is known to be highly correlated with children's welfare measures in the developing world ( $c f$., Appleton, 1995 for Côte d'Ivoire). Gender has a large and significant effect: girls are 19 percentage points less likely than boys to be enrolled.

Note that the following unreported coefficients, although they had statistically extremely insignificant effects in all four regressions in Table 5, control for important aspects of the polygynous household: 1) the number of children of the child's mother and the maximum number of children of the child's other mothers: Because a wife's value is directly related to her ability to bear children (Clignet, 1970, p. 243), the number of children a wife has may affect the father's allocations to her, as well as indicating the level of need; 2) the child's birth order among his fullsiblings (only his mother's children) and among all his siblings (all of his father's children): Evidence suggests children of higher parity tend to receive lower parental investments ( $c f$., Horton, 1988); 3) the number of wives of the child's father: as a measure of the level of competition for resources (Jankowiak, et al., 2005). Note also that these results are robust to limiting the sample to children of marriages with only two co-wives (about two-thirds of the marriages); so the effects are not driven by fathers with many wives. The wealthiest men are the ones who can afford to take third and higher order wives (Jacoby, 1995); since the differences in allocations to senior and junior children are not driven by these families, the differences are unlikely to be caused by a wealth effect.

In unreported results, interaction terms were examined to determine if the effects of the unreported controls differ for senior and junior children, as does the effect of the age difference between wives, but they did not. Also investigated were characteristics of children's family composition which have been argued to affect child well-being in different contexts, without significant results: being the oldest son (de Wolf, 1997); having an oldest sibling who is male (Dahl \& Moretti, 2008); having more brothers (Ssennyonga, 1997), more sisters (Garg \& Morduch, 1998), or more older sisters (Parish \& Willis, 1993), given the size of the sibling set.

\footnotetext{
${ }^{12}$ The exception is the Any Work specification, where the rejection of the null hypothesis that these two coefficients are jointly insignificant has p-value 0.054 .
} 


\subsection{Results for Productive Activities and Educational Attainment}

Turning to the remaining three outcomes in Table 5, we see they display patterns similar to that of enrollment. In column 2 productive activities of children are examined; market work and home production questions were asked about all household members aged seven and over (Venkatamaran, 1996, p. 8). Any Work is an indicator equal to ' 1 ' if the child is reported to have worked in the market or at home in the past week. ${ }^{13}$ In Table 5 column 2 and Figure 1 Panel B we see that the rank of the child's mother affects whether he works or not in a pattern that mirrors that of enrollment. At lower mothers' age gaps, senior and children are essentially equally likely to be working, but this likelihood increases for senior children as the age difference increases. ${ }^{14}$ The difference becomes statistically significant at AgeDiff of 17 years, where the senior child is 6.5 percentage points more likely to be doing any work than the junior child (Figure 1 Panel B). Note that girls are 10 percentage points more likely to do work in the market or home than boys (Table 5 column 2 row 4, coefficient 0.102 ), which suggests that working is not advantageous for these children.

Results for educational attainment (number of years of schooling successfully completed) for this sample and for an older group, aged 20-25, are shown in Table 5, columns 3 and 4, and Figure 2, panels A and B. The older age group is examined because late enrollment and repetition of grades was common during this period in Côte d'Ivoire (Ainsworth, 1996; Den Tuinder, 1978, p. 280), so that many children completed their highest grade attained at later ages than would be expected based on the grade. We see broadly the same results for both age groups: seniors' years of schooling attained decline with increasing mothers' age difference. The deficit for senior children is larger for the older group, suggesting the inequity accrues significantly over time.

\section{CONCLUSIONS}

This paper finds evidence that mother's rank affects allocations to children in polygynous households. This evidence is consistent with the notion that co-wives compete for resources from the husband and invest only in their own children, which can result in inefficient investments in the household's children.

Returning to the assumption that senior and junior children are equally likely to be productive in school, making inequitable investments in their schooling inefficient, there is some suggestive evidence that this assumption is plausible. Table 4 shows that senior and junior children are equally likely to be enrolled in school at ages 7-12, and equally likely to obtain the Certificat $d^{\prime} E$ tudes Primaires by ages 13-19, the diploma granted upon passing the primary school leaving exam. The implication is that their academic abilities are equal, at least at this stage. The regressions control for whether the child's mother has any education, another possible indicator of the child's abilities. Unfortunately, other characteristics of the mothers such as the socioeconomic status of their natal family or the bride price paid by the groom or his family at the time of marriage (Clignet, 1970, p. 243) are unavailable.

\footnotetext{
${ }^{13}$ Market work is defined as "the work on which you spent the most time during the past 7 days, even if you were not paid for it;" home production as, "for example, cleaning the house, preparing meals for your family, washing the family's clothes, buying food or clothes, fetching water or wood for cooking?"

${ }^{14}$ Results for unreported separate regressions of market work and home production are very similar.
} 


\section{A. Years of schooling attained (ages 13-16)}

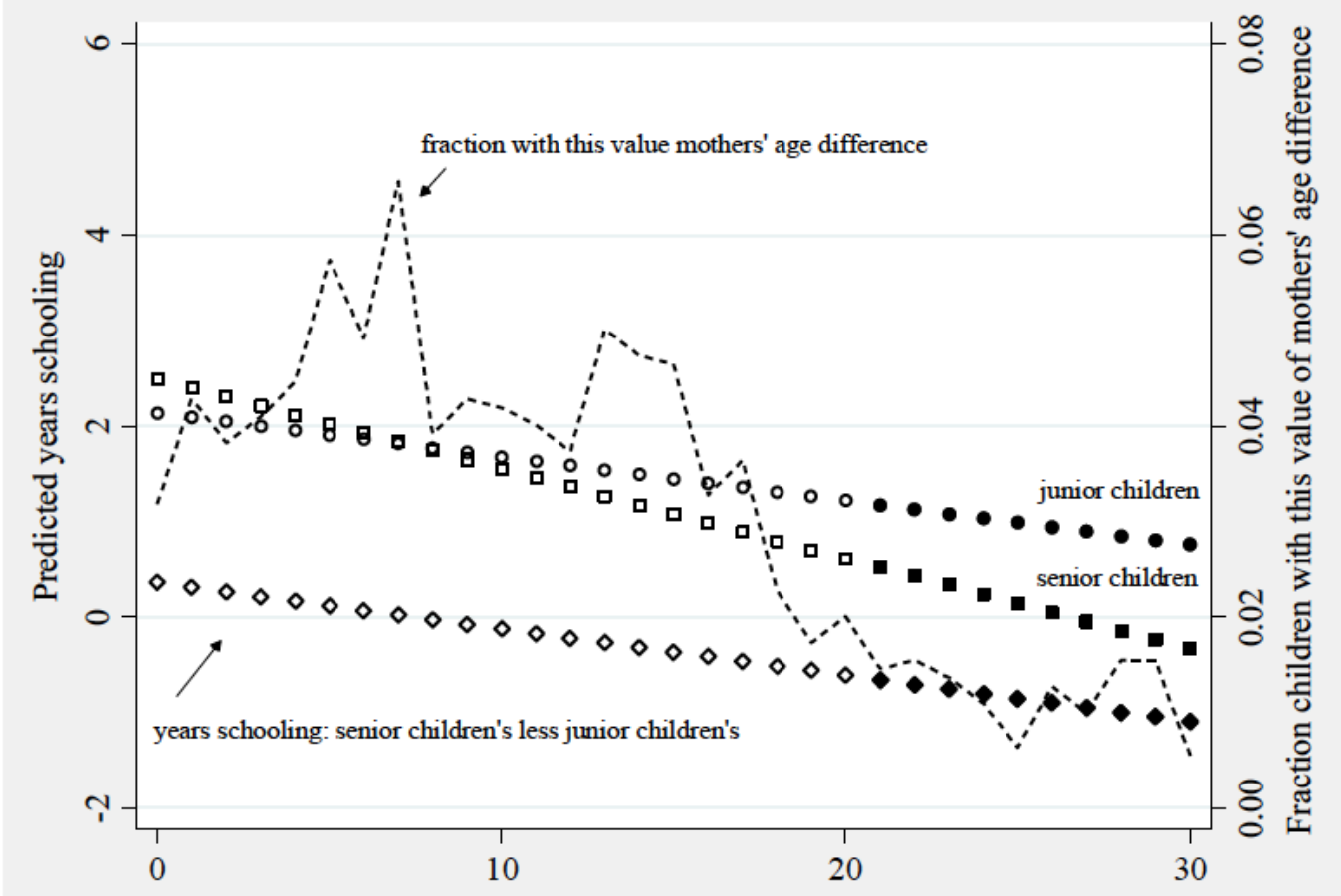

B. Years of schooling attained (ages 20-25)

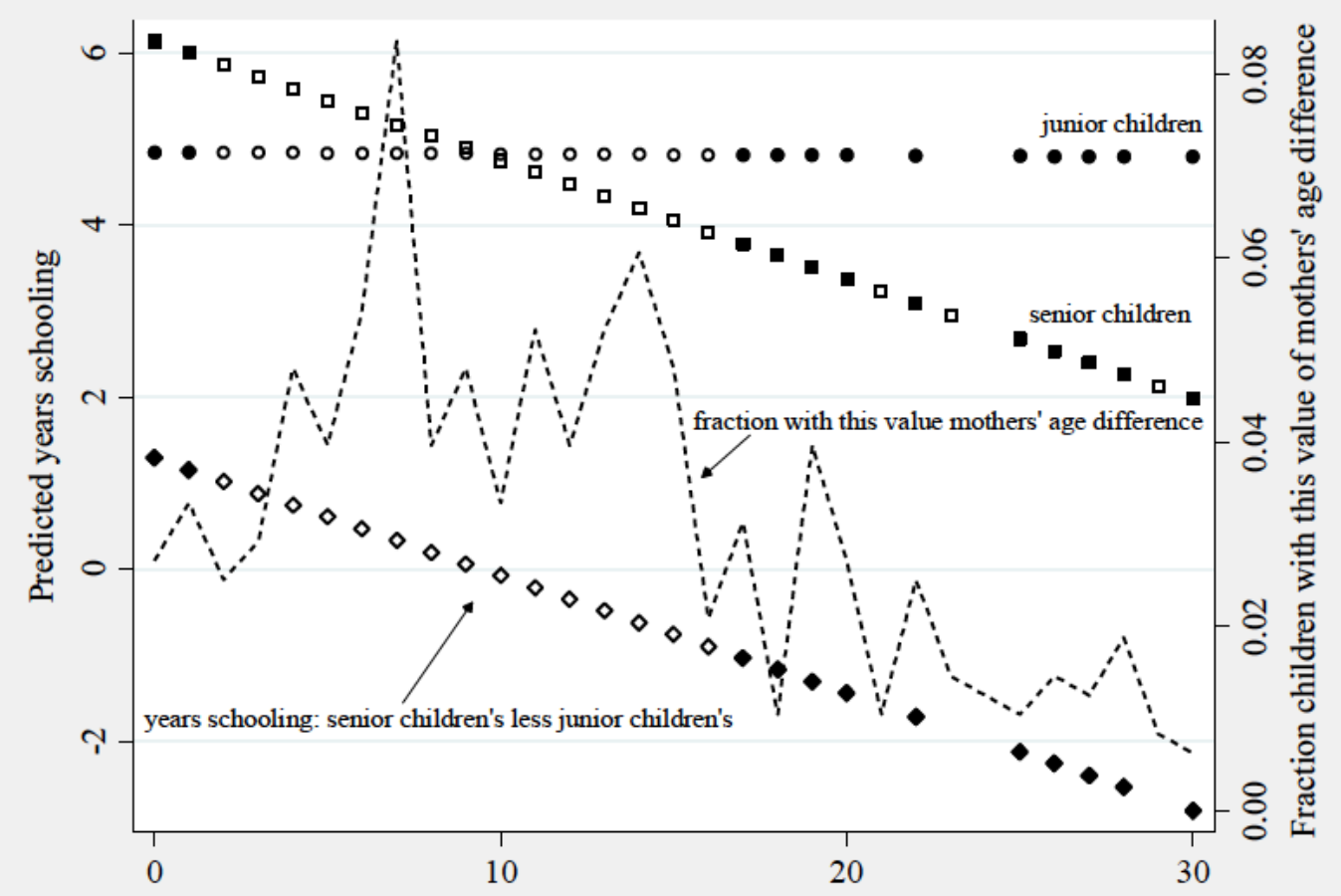

age difference: senior mother's less junior mother's

Figure 2: Polygynous children's educational attainment 
While the findings suggest inefficient investments in polygynous households in Cote d'Ivoire, the results can also be interpreted as being consistent with some scenarios where allocations are efficient. For example, there could be differential returns to education for children of an older senior wife and of a much younger junior wife. Another possibility is that these allocations could be efficient if there are compensating investments that are unobservable to us; for example, Quisumbing (1994) illustrates for the Philippines that daughters receive less education, land, and total inheritance from their parents than sons, but are compensated with nonland assets. It is possible that Ivorian junior children traditionally receive investments not observable in this data, although the ethnographic literature does not appear to support this notion. These scenarios cannot be completely ruled out with the data available.

The finding of inefficient disparity in schooling investments speaks to a role for policies that will incentivize more rational allocations to children, because the disparities potentially affect not only the well-being of the polygynous children but also Côte d'Ivoire as a society. The results here are a snapshot of a particular point in time, but it is unlikely that these investments have rationalized in the intervening years. Polygyny remains prevalent in Côte d'Ivoire. Due to political unrest and dependence on the prices of the main export commodities, coffee and cocoa, the Ivorian economy has periodically surged and stagnated in the years since the CILSS survey, with no notable advancement (World Bank, 2016; ${ }^{15}$ 2015, p. 6). The poverty rate has increased dramatically, and access to secondary education remains inequitable (World Bank, 2015, p. 8, p. 9).

Increasing women's access to credit markets could enable credit-constrained wives to borrow to invest in their children. Greater ability to borrow could also increase investment in their own selfemployment, trading or agriculture, which could give them more income and more clout in the household. ${ }^{16}$ Another possibility would be to target directly the polygynous children's school attendance by paying mothers to keep them in school, similar to the pioneering Progresa program in Mexico. ${ }^{17}$

\section{REFERENCES}

Ainsworth, M. (1996). Economic aspects of child fostering in Côte d'Ivoire. Research in Population Economics, 8, 25-62.

Amankwaa, A. (1996). Prior and proximate causes of infant survival in Ghana, with special attention to polygyny. Journal of Biosocial Science, 28(3), 281-295. doi: $10.1017 / \mathrm{S} 0021932000022355$

Amey, F. (2002). Polygyny and child survival in West Africa. Social Biology, 49(1-2), 74-89. doi:10.1080/19485565.2002.9989050

\footnotetext{
${ }^{15}$ World Bank (2016) shows that Côte d'Ivoire was classified as a lower-middle-income country in the late 1980 s, as low-income in many of the intervening years, and returned to lower-middle-income status in 2008.

${ }^{16}$ See Mayoux (1999) for a discussion of the importance of explicitly including women's empowerment as a component of credit-access programs such as micro-finance initiatives.

${ }^{17}$ There is considerable evidence that allocating resources to mothers rather than the family as a whole has greater positive impact on children's well-being (e.g., Lemay-Boucher \& Dagnelie, 2014).
} 
Amo-Adjei, J., \& Tuoyire, D. A. (2016). Do ethnicity and polygyny contribute to justification of men beating women in Ghana? Women and Health, 56(1), 48-64. doi:10.1080/03630242.2015.1074638

Appleton, S. (1995). The interaction between poverty and gender in human capital accumulation: The case of the primary leaving examination in Côte d'Ivoire. Journal of African Economies, 4(2), 192-224. doi:10.1093/oxfordjournals.jae.a036831

Arthi, V., \& Fenske, J. (2018). Polygamy and child mortality: Historical and modern evidence from Nigeria's Igbo. Review of Economics of the Household, 16(1), 97-141. doi:10.1007/s11150-016-9353-x

Becker, G. (1993). A treatise on the family. Cambridge, MA: Harvard University Press.

Behaghel, L., \& Lambert, S. Polygamy and the intergenerational transmission of education in Senegal. Manuscript. https://www.parisschoolofeconomics.eu/docs/lambertsylvie/dyneg_feb17_4.pdf

Boltz, M., \& Chort, I. (2016). The risk of polygamy and wives' saving behavior. The World Bank Economic Review. doi:10.1093/wber/lhw054

Case, A., \& Paxson, C. (2001). Mothers and others: Who invests in children's health? Journal of Health Economics, 20(3), 301-328. doi:10.1016/S0167-6296(00)00088-6

Clignet, R. (1970). Many wives, many powers: Authority and power in polygynous families. Evanston: Northwestern University Press.

Clignet, R., \& Sween, J. (1969). Social change and type of marriage. American Journal of Sociology, 75(1), 123-145. doi:10.1086/224749

Dahl, G., \& Moretti, E. (2008). The demand for sons. Review of Economic Studies, 75, 10851120. doi:10.1111/j.1467-937X.2008.00514.X

de Laiglesia, J., \& Morrisson, C. (2008). Household structures and savings: Evidence from household surveys. (Working Paper No. 267). Paris: OECD Development Centre. doi: $10.1787 / 245640263431$

de Wolf, J. (1997). Right values and good fortunes: Bukusu responses to ecological opportunity. In T. Weisner, C. Bradley \& P. Kilbride (Eds.), African families and the crisis of social change (pp. 317-331). Westport, CT: Bergin and Garvey.

Den Tuinder, B. (1978). Report of a mission sent to the Ivory Coast by the World Bank: Appendix D. Baltimore: The Johns Hopkins University Press.

Garg, A., \& Morduch, J. (1998). Sibling rivalry and the gender gap: Evidence from child health outcomes in Ghana. Journal of Population Economics, 11(4), 471-493. doi: $10.1007 / \mathrm{s} 001480050080$

Gibson, M., \& Mace, R. (2007). Polygyny, reproductive success and child health in rural Ethiopia: Why marry a married man? Journal of Biosocial Science, 39(2), 287-300. doi: $10.1017 / \mathrm{s} 0021932006001441$

Goldman, N., \& Pebley, A. (1989). The demography of polygyny in sub-Saharan Africa. In R. Lesthaeghe (Ed.), Reproduction and social organization in sub-Saharan Africa (pp. 212238). Berkeley California: University of California Press.

Gould, E. D., Moav, O., \& Simhon, A. (2012). Lifestyles of the rich and polygynous in Côte d'Ivoire. Economics Letters, 115(3), 404-407. doi:10.1016/j.econlet.2011.12.064

Hinks, T., \& Davies, S. (2008). Life satisfaction in Malawi and the importance of relative consumption, polygamy and religion. Journal of International Development, 20(7), 888904. doi:10.1002/jid.1470 
Horton, S. (1988). Birth order and child nutritional status: Evidence from the Philippines. Economic Development and Cultural Change, 36(2), 341-354. doi:10.1086/451655

Ickowitz, A., \& Mohanty, L. (2015). Why would she? polygyny and women's welfare in Ghana. Feminist Economics, 21(2), 77-104. doi:10.1080/13545701.2014.992931

Jacoby, H. G. (1995). The economics of polygyny in sub-Saharan Africa: Female productivity and the demand for wives in Côte d'Ivoire. Journal of Political Economy, 103(5), 938-971. doi:10.1086/262009

Jankowiak, W., Sudakov, M., \& Wilreker, B. (2005). Co-wife conflict and co-operation. Ethnology, 44(1), 81-98. doi:10.2307/3773961

Kazianga, H., \& Klonner, S. (2009). The intra-household economics of polygyny: Fertility and child mortality in rural Mali. MPRA Paper No. 12859, 1-31. http://mpra.ub.unimuenchen.de/12859/

Lemay-Boucher, P., \& Dagnelie, O. (2014). The divorced financial spheres of Beninese spouses. Journal of International Development, 26, 46-58. doi:10.1002/jid.2839

Leroy, J., Razak, A. A., \& Habicht, J. (2008). Only children of the head of household benefit from increased household food diversity in northern Ghana. Journal of Nutrition, 138(11), 2258-2263. doi:10.3945/jn.108.092437

Matz, J. A. (2016). Productivity, rank and returns in polygamy. Demography, 53(5), 1319-1350. doi:10.1007/s13524-016-0506-6

Mayoux, L. (1999). Questioning virtuous spirals: Micro-finance and women's empowerment in Africa. Journal of International Development, 11, 957-984. doi: 10.1002/(SICI)10991328(199911/12)11:7<957::AID-JID623>3.0.CO;2-\%23

Meekers, D. (1992). The process of marriage in African societies: A multiple indicator approach. Population and Development Review, 18(1), 61-78. doi:10.2307/1971859

Munro, A., Bereket, K., Tarazona-Gomez, M., \& Verschoor, A. (2011). The lion's share. an experimental analysis of polygamy in northern Nigeria. (GRIPS Discussion Paper No. 1027). Tokyo: National Graduate Institute for Policy Studies. doi:10.2139/ssrn.1821283

Parish, W., \& Willis, R. (1993). Daughters, education and family budgets: Taiwan experiences. Journal of Human Resources, 28(4), 865-898. doi:10.2307/146296

Pebley, A., \& Mbugua, W. (1989). Polygyny and fertility in sub-Saharan Africa. In R. Lesthaeghe (Ed.), Reproduction and social organization in sub-Saharan Africa (pp. 339365). Berkeley: University of California Press.

Quisumbing, A. (1994). Intergenerational transfers in Philippine rice villages: Gender differences in traditional inheritance customs. Journal of Development Economics, 43(2), 167-195. doi:10.1016/0304-3878(94)90003-5

Solanke, B. L., Kupoluyi, J. A., Abe, J. O., \& Bankole, O. T. (2018). Polygyny and resources for empowerment and equality in Anglo-phone West Africa: Implications for childbearing and women's well-being. European Scientific Journal, 14(17), 174-194.

doi:10.19044/esj.2018.v14n17p174

Ssennyonga, J. (1997). Polygyny and resource allocation in the Lake Victoria basin. In T. Weisner, C. Bradley \& P. Kilbride (Eds.), African families and the crisis of social change (pp. 268-282). Westport, CT: Bergin and Garvey.

Strassmann, B. (1997). Polygyny as a risk factor for child mortality among the Dogon. Current Anthropology, 38(4), 688-695. doi:10.1086/204657 
Sween, J., \& Clignet, R. (1978). Female matrimonial roles and fertility in Africa. In C. Oppong, G. Adaba, M. Bekombo-Priso \& J. Mogey (Eds.), Marriage, fertility and parenthood in West Africa (pp. 565-600). Canberra: Australian National University Press.

Sylla, L. (1992). Ivory Coast. In W. Wickremasinghe (Ed.), Handbook of world education: A comparative guide to higher education and educational systems of the world (pp. 435-442). Houston, Texas: American Collegiate Service.

Tansel, A. (1997). Schooling attainment, parental education, and gender in Cote d'Ivoire and Ghana. Economic Development and Cultural Change, 45(4), 825-856. doi:10.1086/452309

Tertilt, M. (2006). Polygyny, women's rights, and development. Journal of the European Economic Association, 4(2-3), 523-530. doi:10.1162/jeea.2006.4.2-3.523

Timaeus, I., \& Reynar, A. (1998). Polygynists and their wives in sub-Saharan Africa: An analysis of five Demographic and Health Surveys. Population Studies, 52(2), 145-162. doi:10.1080/0032472031000150346

Toungara, J. M. (1994). Inventing the African family: Gender and family law reform in Côte d'Ivoire. Journal of Social History, 28(1), 37-61. doi:10.1353/jsh/28.1.37

Uthman, O., Lawoko, S., \& Moradi, T. (2010). The role of individual, community and societal gender inequality in forming women's attitudes toward intimate-partner violence against women: A multilevel analysis. World Health and Population, 12(2), 5-17. doi:10.12927/whp.2010.22007

Van de Walle, E. (1968). Marriage in African censuses and inquiries. In W. Brass, A. Coale, P. Demeny, D. Heisel, F. Lorimer, A. Romaniuk \& E. van de Walle (Eds.), The demography of tropical Africa (pp. 183-238). Princeton New Jersey: Princeton University Press.

Venkatamaran, M. (1996). Côte d'Ivoire living standards survey (CILSS) 1985-1988: Basic information for users of the data. Washington, DC: World Bank. Retrieved from http://siteresources.worldbank.org/INTLSMS/Resources/33589861181743055198/3877319-1190294521034/CIINFO.PDF

Wagner, N., \& Rieger, M. (2015). Polygyny and child growth: Evidence from twenty-six African countries. Feminist Economics, 21(2), 105-130. doi:10.1080/13545701.2014.927953

World Bank. (2015). Côte d'Ivoire - country partnership framework for the period FY2016FY2019. Washington, D.C.: World Bank Group. Retrieved from http://documents.worldbank.org/curated/en/343341467992463270/Cote-dIvoire-Countrypartnership-framework-for-the-period-FY2016-FY2019

World Bank. (2016). Country and lending groups historical classification by income in XLS format "Country analytical history" for Côte d'Ivoire. Retrieved from landing page: https://datahelpdesk.worldbank.org/knowledgebase/articles/906519-world-bankcountry-and-lending-groups 